\title{
Periprostetik kalça eklemi enfeksiyonu: tanı ve tedavi seçenekleri
}

\section{Periprosthetic hip joint infection: diagnosis and treatment options}

\author{
Doğaç Karagüven ${ }^{1}$, Cem Güneri' ${ }^{1}$, Yasin Köker ${ }^{2}$ \\ 1 Ufuk Üniversitesi Tıp Fakültesi Dr. Rıdvan Ege Hastanesi, Ortopedi ve Travmatoloji Ana Bilim Dalı, Ankara \\ ${ }^{2} 29$ Mayıs Devlet Hastanesi, Ortopedi ve Travmatoloji Kliniği, Ankara
}

Total kalça artroplastisi, ileri evre kalça osteoartritinde sıklıkla uygulanan başarılı bir cerrahi girişimdir. Başarılı bir cerrahi işlem olmasına rağmen, periprostetik eklem enfeksiyonu (PEE) en ciddi komplikasyonlarından bir tanesidir. Bu derleme makalenin amacı, güncel bilgiler ışığında periprostetik kalça eklemi enfeksiyonunda tanı ve tedavi seçeneklerini gözden geçirmektir. Periprostetik kalça eklemi enfeksiyonunu uygun bir şekilde yönetebilmek, her biri zorlu olan klinik şüphe, doğru tanı ve başarılı tedavi basamakları ile mümkündür. Kalça PEE'de tanı; klinik belirti ve bulgular, biyokimyasal testler, görüntüleme yöntemleri, eklem sıvısı analizi, histolojik ve mikrobiyolojik analizlerin bir kombinasyonu ve tanı kriterleri ile konulmaktadır. Enfekte olan kalça artroplastisinin yönetiminde ise beş ana tedavi seçeneği mevcuttur: "antibiyotik ile baskılama", "debridman, yıkama ve implantın korunması", "tek aşamalı revizyon", "iki aşamalı revizyon" ve "kurtarıcı cerrahi yöntemler (rezeksiyon artroplastisi ve amputasyon)". Ciddi morbidite ve hatta mortaliteye sebep olabilen bu durumun en iyi şekilde yönetilebilmesi, cerrahın, kalça PEE konusunda uyanık ve bilgili olması, tanı ve tedavideki gelişmeleri yakından takip etmesinin yanı sıra bu zor ve uzun süreçte dikkatli ve titiz olmasıyla mümkündür.

Anahtar sözcükler: kalça artroplastisi; periprostetik eklem enfeksiyonu; periprostetik kalça eklemi enfeksiyonu; tanı; tedavi

T otal kalça artroplastisi (TKA), ileri evre kalça osteoartritinde sıklıkla uygulanan ve başarılı bir cerrahi girişimdir; hastaların ağrısını rahatlatmak, işlevlerini ve yaşam kalitelerini yükseltmek için maliyet etkinlik analizi yönünden oldukça anlamlı bir çözümdür. Semptomatik kalça osteoartriti, bu cerrahi için en sık endikasyondur.

Başarılı bir cerrahi işlem olmasına rağmen, total kalça artroplastisinde bir takım komplikasyonlar görülebilmektedir. Periprostetik eklem enfeksiyonu (PEE) ise en ciddi komplikasyonlarından biridir. Günümüzdeki yeni antibiyotikler, havalandırma sistemleri, ameliyat öncesi hastanın genel durumunun ve kan değerlerinin
Total hip arthroplasty is a frequently performed and a successful surgical procedure in advanced hip osteoarthritis. Although it is a successful surgical procedure, periprosthetic joint infection (PJI) is one of the most serious complications. The aim of this review article is to review the diagnosis and treatment options in periprosthetic hip joint infection in the light of current information. Appropriate management of periprosthetic hip joint infection is possible with clinical suspicion, accurate diagnosis, and successful treatment steps, each of which is challenging. Hip PJI is diagnosed by a combination of clinical signs and symptoms, biochemical tests, imaging modalities, synovial fluid analysis, histological and microbiological analyses, and diagnostic criteria. There are 5 main treatment options in the management of infected hip arthroplasty: "suppression with antibiotics", "debridement, irrigation, and retention of the prosthesis", "one-stage revision", "two-stage revision" and "salvage procedures (resection arthroplasty and amputation)". The best management of this condition, which can cause serious morbidity and even mortality, is possible if the surgeon is alert and well-informed about hip PJI, closely following the developments in diagnosis and treatment, besides being careful and meticulous in this difficult and long process.

Key words: hip arthroplasty; periprosthetic joint infection; periprosthetic hip joint infection; diagnosis; treatment

optimize edilmesi, cerrahi sürenin kısaltılması, transfüzyon ihtiyacının azaltılması gibi önlemlerle enfeksiyon oranları makul seviyelere kadar gerilemesine rağmen, periprostetik kalça eklemi enfeksiyonu hâlâ morbiditenin önemli sebeplerinden biri olmaya devam etmektedir ve bu klinik durumu uygun bir şekilde yönetebilmek önem arz etmektedir.

Periprostetik kalça eklemi enfeksiyonunun uygun bir şekilde yönetimi ise her biri zorlu olan klinik şüphe, doğru tanı ve başarılı tedavi basamakları ile mümkündür. "Altın standart" bir tanı aracı olmamasına rağmen, son zamanlarda, periprostetik eklem enfeksiyonu tanısı adına büyük adımlar atılmıştır.

iletişim / Contact: Dr. Öğr. Üyesi Doğaç Karagüven • E-posta / E-mail: dogackaraguven@gmail.com

ORCID iD: Doğaç Karagüven, 0000-0003-2360-3907 • Cem Güneri, 0000-0002-6298-9876 • Yasin Köker, 0000-0002-8392-1846

Geliş / Received: 9 Eylül 2021 • Kabul / Accepted: 29 Eylül 2021 
Bu derlemenin amacı, güncel bilgiler ışı̆̆ında periprostetik kalça eklemi enfeksiyonunda tanı ve tedavi seçeneklerini gözden geçirmektir.

\section{TANI}

Kalça periprostetik eklem enfeksiyonunun başarılı bir şekilde tedavisi, öncelikle doğru bir tanı ile mümkündür. Ancak ne yazık ki, onlarca yıllık araştırmalara rağmen gerçek bir "altın standart" tanı testi veya aracı henüz mevcut değildir. Tanı, çoğunlukla; klinik şüphe, klinik belirti ve bulgular, biyokimyasal testler, görüntüleme yöntemleri, eklem sıvısı analizi, histolojik ve mikrobiyolojik analizlerin bir kombinasyonu ile konulabilmektedir.

\section{Hikâye ve Fizik Muayene - Klinik Özellikler}

Laboratuvar ve görüntüleme yöntemlerindeki gelişmeler, periprostetik eklem enfeksiyonu tanısını kolaylaştırmış olsa da, klinik şüphe ile kapsamlı hikâye ve fizik muayene, değerlendirmenin ilk ve temel basamağı olarak kalmaya devam etmektedir.

Hikâye, primer kalça artroplastisi için altta yatan durumla (osteoartrit, romatoid artrit, osteonekroz, femur boyun kırığı vb.) başlar. Hastanın mevcut şikâyeti, semptomları ve bunların başlangıç zamanı, ameliyattan sonra semptomsuz rahat bir döneminin olup olmadığı, geçirdiği cerrahi sayısı ve tarihleri sorgulanmalıdır. Gecikmiş veya kötü yara iyileşmesi hikâyesi (uzamış yara yeri akıntısı, yara ayrılması (dehiscence) veya yüzeyel enfeksiyon), ameliyat sonrası uzun süre antibiyotik kullanımı, tekrar ameliyat gereksinimi ve hematojen yayılıma sebep olabilecek girişimsel işlemler, vücudun başka bir bölgesinde enfeksiyon odağı olup olmadığı (idrar yolları, diş vb.), yeni bir bakteriyemi gibi durumlar sorgulanmalı ve not edilmelidir.

Periprostetik eklem enfeksiyonunun klinik sunumu zaman zaman belirgin olsa da, daha sıklıkla belirsiz ve non-spesifik bulgularla karşımıza çıkmaktadır; bu durum enfeksiyonu, aseptik gevşemeden ayırt etmeyi zorlaştırır. Sıklıkla belirtilen semptom ve fizik muayene bulguları; kalça ekleminde ağrı, kesi bölgesinde eritem, akıntı, eklemde ısı artışı, ateş ve sinüs yoludur. ${ }^{[1]}$

Ağrı, periprostetik eklem enfeksiyonunda en sık görülen semptomdur ve $\% 42-\% 100$ oranlarında bildirilmektedir.[1] Ağrının bölgesi, başlangıcı, karakteri, ciddiyeti, yayılımı, ağrıyı artıran ve azaltan sebepler ile sistemik semptomlar sorgulanmalıdır. Cerrahiden itibaren, ağrısız bir dönem olmaksızın ısrarcı ağrı, enfeksiyon veya spinal stenoz, radikülopati gibi atlanmış bir durum lehinedir. Diğer yandan, yıllarca ağrısız ve iyi işlevli bir kalça protezi döneminden sonra yeni başlangıçlı, uyluk ve kasık çevresindeki harekete geçme ağrısı (örneğin, sandalyeden kalkarken ve yürürken) mekanik gevşeme lehinedir. Yük verme ve hareket ile artan, dinlenmekle rahatlayan mekanik ağrı da gevşeme lehinedir. ${ }^{[2]}$ Hasta istirahatte iken veya gece ortaya çıkan ağrının da enflamatuvar bir süreci temsil edebileceği akılda tutulmalı ve cerrahi alan enfeksiyonu olasılığına karşı uyanık olunmalıdır.

Drenaj, en sık görülen ikinci semptomdur ve ameliyattan birkaç hafta sonra hâlâ mevcutsa, kuvvetle enfeksiyonu düşündürür. Ağrısı devam eden bir hastada ameliyat sonrası uzamış drenaj öyküsü doğru tanıyı koymada çok yardımcı olabilir. ${ }^{[3]}$

Hikâyede ayrıca; ASA (American Society of Anesthesiologists) skorunun $>2$ olması, idrar yolu enfeksiyonu, romatoid artrit, beden kitle indeksinin $>40$ olması, insülin bağımlı diabetes mellitus, hepatopati, nefropati ve alt ekstremite vasküler hastalığı, malnütrisyon, erken implant gevşemesi ( $<5$ yıl), erken osteoliz ( $<5$ yıl), immunsüpresyon, uzamış ameliyat süresi $(>2,5$ saat) gibi risk faktörleri sorgulanarak hastanın PEE açısından riski belirlenmeli ve yüksek riskli hastalarda daha yüksek şüphe ile ilerlenmelidir. ${ }^{[4-6]}$

Klinik muayenede kalça ile birlikte, diz eklemi ve lomber omurga da muayene edilmeli; yürüyüş paterni, ağrısız eklem hareket açıklığ, şişlik, kızarıklık, yara çevresi ve insizyonel problemlere odaklanılmalıdır. Aktif hareket açıklığı veya rotasyonun uç noktalarında ortaya çıkan ağrı, bileşen (komponent) gevşemesini gösterir. Dirence karşı ipsilateral düz bacak kaldırma ile ağrı, kalça patolojisini; ipsilateral veya kontralateral pasif düz bacak kaldırma ile ağrı ise radikülopati veya lomber omurga patolojisini düşündürür. Spinal patoloji veya nöropatiyi dışlamak için her iki alt ekstremitenin nörolojik muayenesi yapılmalı ve vasküler patolojileri dışlamak için de periferik nabızlar kontrol edilmelidir. Kalçanın daha ayrıntılı değerlendirilmesi, bacak uzunluğunun değerlendirilmesini içerir. Örneğin, bacağın ilerleyici kısalması, femoral bileşen çökmesini veya asetabular bileşen migrasyonunu gösterebilir. Diğer taraftan, belirgin bir tutarsızlık, kalçanın abduksiyon veya adduksiyon kontraktürünü, pelvisin oblikliğini veya lomber skolyozu gösterebilir. ${ }^{[2]}$

Periprostetik eklem enfeksiyonunda, akut (eklem ağrısı, kızarıklık, ısı artışı, selülit, cerrahi yara akıntısı ve ateş) ve kronik (ilerleyici ağrı, fistül oluşumu ve ateş olmadan pürülan sekresyonların drenajı) olarak ayrılabilen karakteristik klinik belirtilerle karşılaşılabilir. Akut enfeksiyonlar, genellikle PEE'yi düşündüren daha fazla sayıda bulgu ve belirtiye sahiptir. Buna karşılık, kronik PEE, implantasyondan sonraki 2-3 yıl içinde erken implant yetmezliğinin de eşlik edebildiği ısrarcı eklem ağrısı ile karakterize yavaş bir seyir gösterir. Son zamanlarda, implant uygulanmasından sonraki iki yıl içinde protezin gevşemesinin, yüksek 
oranda enfeksiyonla ilişkili olduğu gösterilmiştir. Kronik PEE'li hastalarda genellikle PEE'nin yukarıda belirtilen akut belirti ve semptomlarının çoğu görülmez, bu da protezin aseptik gevşemesinden ayırt edilmesini zorlaştırır. ${ }^{[7]}$

\section{Biyokimyasal Testler}

Biyokimyasal testler, ağrılı eklem artroplastisi olan ve revizyon cerrahisi planlanan hastaların ilk değerlendirilmesinde yararlı bir tarama yöntemidir. Tam kan sayımı ve polimorfonükleer lökosit (PMNL) yüzdesi, eritrosit sedimentasyon hızı (ESH) ve C-reaktif protein (CRP) kolay ulaşılabilir ve maliyet etkin testlerdir. Asemptomatik hastalarda, kalça protezlerini takiben ESH'nin normale dönmesi bir yılı bulabilirken, CRP seviyesi 3-4 hafta içinde normale döner ${ }^{[8]}$, bu nedenle serum CRP değerleri, ESH değerlerine göre ameliyat sonrası dönemde daha duyarlıdır. Eritrosit sedimentasyon hızının $30 \mathrm{~mm} /$ saat'ten yüksek veya serum CRP değerlerinin 5-10 mg/L'den yüksek olması PEE'yi düşündürür. Pozitif bir ESH veya pozitif serum CRP, sırasıyla \%94-\%98 duyarlılık ve \%59-\%77 özgüllük sağlar[7], ancak hem ESH hem de CRP seviyesinin birleştirilmesi, duyarlılığı \%97,6'ya yükseltmektedir. ${ }^{[9]}$ Her iki test de negatif sonuç veriyorsa, PEE riski düşüktür (iyi negatif prediktif değer). Her iki testin de pozitif sonuç vermesi periprostetik enfeksiyona özgü değildir çünkü bu değerler, başka bir enfeksiyon odağı, neoplazi veya başka enflamatuvar durumlarda da yükselebilmektedir; ancak yine de, iki testin de pozitif olması PEE şüphesini artırmaktadır. Bu nedenle, bu testler daha çok bir dışlama aracı olarak hizmet etmektedir. ${ }^{[5,10]}$

Tam kan sayımı ve PMNL yüzdesi de yol gösterici olabilmekle birlikte, geç kronik enfeksiyonda, periferik beyaz küre sayısı nadiren yükselir ve bu durumda, bu, hassas bir tarama aracı değildir. ${ }^{[2]}$ Ancak beyaz küre sayımı ile PMNL yüzdesi eklem sıvısından bakıldığında daha değerlidir.

Bunlarla birlikte, interlökin-6, prokalsitonin, tümör nekroz faktörü- $\alpha$, D-dimer gibi serumdan bakılabilen birçok yeni belirteç üzerinde de çalışılmaktadır. Ancak bunların birçoğu araştırma aşamasındadır ve bu aşamada tanı kriterleri arasına yalnızca D-dimer dâhil edilmiştir. ${ }^{[11]}$

\section{Tanısal Görüntüleme}

Ağrılı kalça artroplastisi olan tüm hastalar için, anteroposterior pelvis grafisi ve ilgili kalçanın lateral grafisi gerekli olmakla birlikte, bunlar nadiren enfeksiyon için tanısaldır. Direkt grafide radyolüsent çizgiler (özellikle ilk beş yılda), fokal osteoliz, erken gevşeme (özellikle ilk beş yılda) veya periosteal kemik oluşumu varsa PEE tanısında yardımcı olabilir. Bu radyografik bulgulardan özellikle periosteal kemik oluşumu, derin periprostetik enfeksiyonu kuvvetle düşündürür. Radyolüsent çizgilerin varlığı genellikle aseptik ile septik gevşemenin ayırt edilmesine izin vermez. Femoral kanalla ilgili endosteal erozyonlar yaygın radyografik bulgulardır, ancak hem aseptik hem de septik gevşeme ile ortaya çıkabilir. Bu bulguların seri radyografilerde izlenmesi daha değerlidir ve seri radyografilerde bileşenlerin çökmesi ve migrasyonu ile protez çevresinde ilerleyici radyolüsent çizgiler yol gösterici olabilir. ${ }^{[2,3,5]} \mathrm{Ne}$ yazık ki, bu bulgulardan herhangi birinin olmaması, bir enfeksiyonun varlığını ekarte ettirmez.

Nükleer tıp çalışmaları ise, sadece sinovyal sıvının aspirasyonla elde edilemediği ve PEE için klinik şüphenin yüksek olduğu nadir durumlarda kullanılmaktadır. Tercih edilen testlerden bir tanesi Indium (In)111 beyaz kan hücresi taramasıdır. Radyonükleotid görüntüleme genel olarak düşük özgüllüğe sahiptir ve özellikle PEE tanısı belirsiz olduğunda negatif bir tarama ile enfeksiyonun yokluğunu öngörmede daha yardımcı olabilir. Bu testlerin duyarlılığı ve özgüllüğü, "üç fazlı" bir tarama olarak kombinasyon halinde (Teknesyum [Tc]-99, In-111 ve kükürt kolloid taramaları) kullanılarak geliştirilebilir. ${ }^{[12]}$ Sonuçların değişkenliği ve ek zaman, maliyet gerektirmesi nedeniyle, özellikle klinik şüphenin yüksek olduğu ve/veya tanının birinci basamak testlerle konulduğu durumlarda, bu testlerin kombinasyon halinde veya tek başına rutin kullanımı önerilmez. ${ }^{[5]}$

Ultrasonografik görüntüleme, effüzyonu kanıtlamak ve aseptik aspirasyonu kolaylaştırmak için kullanılabilecek bir başka non-invaziv görüntüleme yöntemidir. ${ }^{[9]}$

Manyetik rezonans (MR) görüntülemenin periprostetik kalça enfeksiyonu yönetiminde önemli bir role sahip olabileceği Zanetti tarafından belirtilmiştir. Zanetti, MR'nin; periost reaksiyonu, kapsüler ödem, kas içi ödem, cerrahi yaklaşım alanında deri altı sıvı toplanması, kas içi sıvı toplanması, bu sıvı birikimlerinin eklem ile ilişkilerinin varlı̆̆ı ve inguinal lenfadenopati gibi periprostetik kalça eklemi enfeksiyonu olasılığını artıran pozitif bulguları ortaya çıkarabileceğini; ayrıca ayıııı tanıda abduktor tendon anormallikleri, bursit, sinovit ve ters (adverse) lokal doku reaksiyonu ile ilişkili osteolizin değerlendirilmesinde yararlı olabileceğini belirtmiştir. Son olarak, MR'nin en yaygın sıvı birikiminin yerini belirleyerek eklem sıvısı aspirasyonunu yönlendirmeye yardımcı olabileceğinden bahsetmiştir. ${ }^{[13]}$ Bunlarla birlikte, MR görüntüleme ve bilgisayarlı tomografinin (BT) PEE tanısındaki rolleri, yüksek maliyetleri ve düşük özgüllükleri nedeniyle sınırlıdır. Şu anda PEE tanısında MR/BT kullanımını önermek için yeterli kanıt yoktur. Bunlara dayanarak, AAOS (American Academy of Orthopaedic Surgeons 
- Amerikan Ortopedik Cerrahlar Akademisi), MR ve BT'nin kullanımına yönelik olumlu ya da olumsuz bir öneride bulunmamıştır. ${ }^{[5,14]}$

Florodeoksiglukoz - pozitron emisyon tomografisi (FDG-PET) taraması, artan metabolik aktiviteye sahip alanların görüntülenmesini sağlar ve bu da enfeksiyonu düşündürür. Chryssikos ve ark., 127 ağrılı kalça protezi hastasında yaptıkları bir çalışmada, FDG-PET için duyarlılık, özgüllük, pozitif ve negatif prediktif değerleri sırasıyla $\% 85, \% 93, \% 80$ ve $\% 95$ bulmuşlardır. Bu yeni invaziv olmayan görüntüleme yönteminin genel doğruluğu, bu çalışmada \%91'e ulaşmıştır. Yazarlar, FDG-PET'i, septik ağrılı kalça protezlerini aseptik ağrılı kalça protezlerinden ayırt etmek için umut verici ve doğru bir tanı aracı olarak görmektedir. ${ }^{[15]}$ Ancak, literatürde FDG-PET ile ilgili çalışmaların sonuçları heterojendir. FDG-PET'in tanı potansiyeli açıktır, ancak daha fazla çalışmaya ihtiyaç vardır.

\section{Eklem Sıvısı Aspirasyonu, Analizi ve Kültür-Antibiyogram}

Hikâye, fizik muayene, kan testleri ve görüntüleme yöntemlerini takiben, kalça aspirasyonu enfeksiyon şüphesi olan hastalarda bir sonraki adımdır. Bu işlem, tam bir cerrahi steriliteyi sağlamak için, genellikle ameliyathane şartlarında, lokal anestezi eşliğinde ve floroskopi rehberliğinde yapılır. Aspire edilen sıvı, daha sonra gram boyama, kristal incelemesi, kültür ve antibiyogram, hücre sayımı, biyokimyasal analiz için ilgili bölümlere yönlendirilir. Aspirasyon ile sıvı alınamazsa, eklemin steril serum fizyolojik ile yıkanması ve bu sıvının analiz edilmesi önerilmemektedir. ${ }^{[5]}$ Eklem sıvısı kültürünün negatif geldiği veya eklem sıvısının aspire edilemediği, ancak şüphenin yüksek olduğu durumlarda, doku biyopsisi için artroskopi veya artrotomi gerekebilir; bu, hassasiyeti ve kesinliği artıracaktır. ${ }^{[16]}$

Sinovyal sıvıda beyaz küre (BK) sayımı, birçok çalışmada kronik derin enfeksiyon tanısında mükemmel özgüllük ve duyarlılık göstermiştir. Son zamanlarda yapılan çok sayıda çalışmaya dayanarak, "PEE üzerine Uluslararası Konsensus", kronik PEE için eşik değerleri sinovyal sıvı BK sayımı için $>3000$ hücre/ $\mu \mathrm{L}$ ve diferansiyel için >\%80 PMNL olarak önermektedir. Cerrahiden sonraki altı hafta içinde alınan sinovyal sıvıdaki eşik değerler ise, BK için >10 000 hücre/ $\mu \mathrm{L}, \mathrm{PMNL}$ için $>\% 90$ olarak kabul görmüştür. ${ }^{[17]}$

Sinovyal sıvı biyobelirteçleri PEE tanısında çok önemli bir rol oynamaktadır. Bunlar iki ana gruba ayrılabilir: sitokinler ve antimikrobiyal işlevlere sahip biyobelirteçler. Bu biyobelirteç grubuyla ilgili sorun, özgüllüklerinin düşük olmasıdır ve bu belirteçler, romatoid artrit gibi, eklemin diğer enflamatuvar durumlarında da yükselebilir. Daha spesifik sinovyal sıvı biyobelirteçleri şunlardır: lökosit esteraz (LE), $\alpha$-defensin, $\beta$-defensin, sinovyal CRP ve katelisidin LL-37. [18]

Periprostetik eklem enfeksiyonu durumunda, eklem içine gelen nötrofiller tarafindan salgılanan bir enzim olan LE, renk değişikliği ile sonuçlanan reaksiyonlar yoluyla, kolorimetrik strip testleri kullanılarak tespit edilebilir. Lökosit esteraz, sinovyal sıvının, bir idrar test stribine uygulanmasını gerektiren, basit ve kolayca bulunabilen bir testtir. Hassasiyeti ve özgüllüğü sırası ile $\% 79$ (\%95 güven aralığında \%75-\%82) ve \%96 (\%95 güven aralığında \%95-\%97)'dır. ${ }^{[19]} 2018$ yılında yayımlanan periprostetik eklem enfeksiyonu tanımının minör kriterlerinin de bir parçasıdır. ${ }^{[11]}$ Lökosit esteraz testinin bir kısıtlılığı, kolorimetrik bir test olması nedeniyle, örneklenen eklem sıvısının kan içermesi durumunda yorumlanamaz/geçersiz sonuçlar vermesidir. ${ }^{[20]}$

Enfekte eklem replasmanına yanıt olarak nötrofiller tarafindan üretilen bir sinovyal sıvı peptidi olan $\alpha$-defensin de güncel tanı kriterleri ${ }^{[11,21]}$ arasına girmiş olup, bu testin duyarlılığı ve özgüllüğü sırası ile $\% 87$ (\%95 güven aralığında \%83-\%90) ve \%97 (\%95 güven aralığında \%96-\%98)'dir. ${ }^{[19]}$

Periprostetik eklem enfeksiyonu olgularında, hem serumda hem de sinovyal sıvıda yükselen CRP, makrofajların arttığı durumlarda akut enflamasyona yanıt olarak karaciğerde sentezlenen bir proteindir. Parvizi ve ark., septik ve aseptik hastaları karşılaştırarak, sinovyal sıvı CRP ortalamalarında istatistiksel olarak anlamlı bir fark bulmuşlardır (aseptik grupta ortalama 2 $\mathrm{mg} / \mathrm{L}$, septik grupta ortalama $40 \mathrm{mg} / \mathrm{L}[\mathrm{p}<0,0001])$. Çalışma, sinovyal sıvı CRP için eşik değer $9,5 \mathrm{mg} / \mathrm{L}$ olarak kabul edildiğinde, \%85'lik bir duyarlıık ve \%95'lik bir özgüllük bulmuştur. ${ }^{[22]}$

İnsan konak savunma peptidi LL-37, katelisidinlerden biridir ve IL-8 (interlökin 8) gibi aracıları indükleyen, enflamatuvar yanıtı düzenleyen bir antimikrobiyal peptittir. Gollwitzer ve ark., LL-37'nin sinovyal sıvida yükseldiğini göstermiş ve PEE hastalarında, \%80 duyarlılık ve \%85 özgüllük bildirmişlerdir. ${ }^{[23]}$

Enfeksiyona neden olan mikroorganizmaları izole etmek, tanımlamak ve antibiyotik duyarlılıklarını belirlemek için kültürler ve antibiyogram hâlâ gereklidir. Kültürlerin duyarlııkları zayıf ve yalancı negatiflikleri fazladır; bu nedenle negatif bir kültür, PEE olasılığını dışlamaz. Kültürde üreme ihtimalini artırmak için çeşitli önlemler alınmalıdır. Kültürler alınmadan en az iki hafta önce antibiyotikler durdurulmalıdır, ancak bazı yavaş üreyen mikroorganizmaların büyümesinin, bilinçsizce kullanılan kısa bir antibiyotik uygulaması ile bile aylarca engellenebileceğini bilmek önemlidir. Bu nedenle, altta yatan patojeni maskelememek adına, hastanın sistemik ve hayatı tehdit edici bir yetmezliği 
yoksa, ampirik antibiyotik başlanması önerilmemektedir. Kan kültürü şişeleri gibi zenginleştirilmiş besi yerlerinde sinovyal sıvı örneklerinin gönderilmesi mikroorganizmanın izole edilmesi ihtimalini artıran bir başka önlemdir. Örnekler aerobik ve anaerobik kültürler için gönderilmelidir. Aside dirençli basil veya mantar kültürleri, şüpheli bir kültür-negatif enfeksiyon durumunda veya atipik bir etiyoloji için klinik şüphenin yüksek olduğu hastalarda gönderilmelidir. Uzatılmış inkübasyon (14-21 gün) Propionibacterium acnes gibi daha yavaş üreyen organizmalar için yararlı olabilir; yüksek şüphe ve kültür-negatif durumlarda düşünülebilir. Bunlar dışında üç günlük bir kültür süresi yeterli olarak görülmektedir. ${ }^{[5]}$ Enfekte total kalça artroplastisinde en yaygın olarak izole edilen organizmalar S.aureus ve S.epidermidis'tir ve bunu gramnegatif bakteriler izler. ${ }^{[24]}$

\section{Ameliyat Sırasında Tanı}

Özellikle belirsiz bir tanı durumunda veya klinik şüphenin yüksek olduğu durumlarda, PEE tanısı için "ameliyat sırasında testler" sıklıkla kullanılır. Ameliyat sırasında alınan gram boyama, kültürler ve donmuş kesitler (frozen section), ameliyat öncesi tanı net olmadığında, çoğu zaman belirleyici faktör olabilir. Bununla birlikte, ideal bir ortamda, PEE tanısı cerrahi müdahaleden önce, diğer modaliteler yoluyla konmalı veya dışlanmalıdır.

Ameliyat sırasında gram boyama, PEE tanısı için tek başına yeterli bir test değildir ve AAOS, bunun ameliyat sırasında tanıyı dışlamak için kullanılmasına karşı çıkmaktadır. ${ }^{[14]}$

Polimeraz zincir reaksiyonu (PZR) ve enzime bağlı immunosorbent assay (ELISA) teknikleri, periprostetik eklem enfeksiyonlarının saptanmasında son derece hassastır. Bununla birlikte, PZR aktif ve eradike edilmiş enfeksiyonlar arasında ayrım yapamaz ve rutin klinik kullanım için mevcut olmayan pahalı bir araştırmadır.

Mikrobiyoloji ve histopatolojik analizin de PEE tanısında yerleri vardır ve bunlar için ameliyat sırasında birden fazla doku örneği gönderilmelidir. Atkins ve ark., ameliyat sırasında beş veya altı örnek gönderilmesini, eşik değer için ise en az üç örnek gönderilmesini önermektedir. ${ }^{[25]}$ Histoloji için önerilen üç örneğin, birincisinin yalancı kapsülden, ikincisinin asetabular bileşen ve kemik arasındaki veya asetabular kemik-çimento ara yüzündeki membrandan, üçüncüsünün ise femoral komponent ve femur arasındaki veya femoral kemikçimento ara yüzündeki membrandan gönderilmesi önerilmektedir. ${ }^{[3]}$ Ameliyat sırasında donmuş kesitler, numuneler uygun yerlerden alınmadığında, numune alma hatasına yatkın olabilir. Spesifik olarak histolojik başarı, cerrahın numune toplaması ile birlikte patoloğun da öznel yorumuna bağlıdır. Yüksek büyütme alanı (YBA) (400× büyütme) başına nötrofil sayısı için eşik değerler tartışmalıdır. Meta-analizlerinde Della Valle ve ark., YBA başına 10'dan fazla nötrofil içeren bir donmuş kesitin, yüksek oranda enfeksiyonu düşündürdüğü (yüksek özgüllük), ancak negatif bir sonucun enfeksiyon olasılığını dışlamadığı (düşük duyarlılık) sonucuna varmıştır. ${ }^{[26]}$ Parvizi ve ark. tarafından 2018 yılında oluşturulan tanı kriterlerinde ise, ameliyat sırasında donmuş kesitler için sınır, $>5$ nötrofil/YBA olarak belirlenmiştir. [11] Yine 2021 yılında yayımlanan Avrupa Kemik ve Eklem Enfeksiyon Cemiyeti (European Bone and Joint Infection Society - EBJIS) kriterlerinde de, sınır $>5$ nötrofil/YBA olarak belirtilmiştir. ${ }^{[21]}$ Ameliyat sırasında alınan donmuş kesitlerin, yeniden implantasyondan önce, iki aşamalı değişim artroplastisinin ikinci kısmı sırasında da, enfeksiyonun eradikasyonunu teyit etmede rolleri olabilir, ancak düşük duyarlılığa sahip oldukları akıldan çıkarılmamalıdır.

Ameliyat sırasında alınan kültürler, enfeksiyona neden olan organizmayı tanımlamanın en güvenilir yollarından biridir. Kültürlerde mikroorganizmayı üretebilme şansı da, yine, revizyon cerrahisi sırasında dikkatli örneklemeye bağlıdır. Farklı, temsili alanlardan, tercihen protez bileşenleri ile konakçı kemik veya doku arasındaki ara yüzden çoklu (en az üç, tercihen beş veya daha fazla) kültürler alınmalıdır. Genellikle sürüntü kültürlerinden kaçınılması ve bunun yerine dokunun steril bir kaba yerleştirilerek hızlı bir şekilde laboratuvara gönderilmesi önerilmektedir. ${ }^{[5]}$ Kültürde mikroorganizmanın izole edilme şansını artırmak için, antibiyotik kullanımına dikkat edilmesi gibi, daha önce belirtilen durumlara dikkat edilmelidir.

Çıkarılan protezler veya bileşenler, kültür ve sonikasyon (organizmaların protezlerden izolasyonunu artıran bir işlem) için kullanılabilir. Trampuz ve ark., kalça periprostetik eklem enfeksiyonunun teşhisinde periprostetik sonikat-sıvı kültürünün duyarlılı̆gının $(\% 78,5)$, tek bir periprostetik doku kültüründen $(\% 60,8)$ daha yüksek olduğunu bulmuştur $(p<0,001)$ ve özgüllük hemen hemen değişmeden kalmıştır (\%99,2'ye karşı \%98,8). Duyarlılıktaki iyileşme, yakın zamanda antibiyotik uygulanan hastalarda yapıldığında, daha da belirgin olarak saptanmıştır (\%45'ten $\% 75^{\prime}$ e). ${ }^{[27]}$

\section{Tanı Kriterleri}

Yukarıda anlatılan, hikâye ve fizik muayene, biyokimyasal testler, görüntüleme yöntemleri, eklem sıvısı analizi yöntemlerinin tek başlarına duyarlılık ve/veya özgüllükleri düşüktür. Bu nedenle, bu tanı araçlarının kombinasyonlarına sahip birden çok tanı kriteri seti geliştirilmiştir. 
Bu makalede bu kriterlerden güncel olan 2018 yılında Parvizi ve ark. tarafindan yayımlanan tanı kriterlerine $^{[11]}$ ve 2021 yılında yayımlanan Avrupa Kemik ve Eklem Enfeksiyonu Cemiyeti (European Bone and Joint Infection Society - EBJIS) tanı kriterlerine ${ }^{[21]}$ kısaca değinilecektir.

Kas-ìskelet Enfeksiyon Cemiyeti (The Musculoskeletal Infection Society - MSIS) ve Enfeksiyon Hastalıkları Derneği (Infectious Diseases Society - IDSA) daha önce PEE tanımını standardize etmek için kriterler geliştirmiştir. 2013'teki bir başka konsensus toplantısı (International Consensus Meeting - ICM), MSIS'in PEE tanımını onaylayarak biraz değiştirmiştir. ${ }^{[8]}$ Daha sonra, Parvizi ve ark., 2018 yılında, PEE tanısındaki güncel gelişmeler ışığında, uzman görüşünden çok, kanıta dayalı bir yaklaşımla bu kriterleri modifiye ederek üç aşamalı bir tanı kriteri geliştirmiştir (Tablo 1). ${ }^{[11]}$ Bu skorlama sisteminin genel duyarlılığı ve özgüllüğü sırasıyla $\% 97,7$ ve \%99,5 olarak belirtilmiştir. Bu tanı kriteri, ICM $(\% 86,9)$ ve MSIS $(\% 79,3)$ tanımlarına kıyasla benzer özgüllükle daha yüksek bir duyarlılık göstermiştir. Bu mükemmel performansa rağmen, yazarlar yine de, klinik muhakemenin ön planda tutulması ve doktorlara rehberlik etmesi gerektiğini; bir hastanın enfekte olduğu halde tanı kriterlerini karşılamadığı durumların veya bunun tersi durumların olabileceğini belirtmişlerdir. Ayrıca ters lokal doku reaksiyonu (Adverse Local Tissue Reaction - ALTR), kristal artropatileri, enflamatuvar artropati alevlenmeleri ve yavaş üreyen mikroorganizmalarla enfeksiyon gibi durumlarda dikkatli olunması gerektiğinin ve bu tanımlanan kriterlerin bu gibi durumlarda yanıltıcı olabileceğinin altını çizmişlerdir. ${ }^{[11]}$

2018'deki bu yeni tanı kriterleri, yeniden toplanan "Uluslararası Konsensus Toplantısı (International Consensus Meeting - ICM)"nda tartışılmıştır, ancak delegelerin yalnızca \%68'i tarafından desteklenmiştir. ${ }^{[28]}$ Kas-i̇skelet Enfeksiyon Cemiyeti (MSIS) veya EBJIS tarafından onaylanmamış ve 2021 yılında EBJIS kriterleri yayımlanmıştır. Bu kriterler de Tablo 2'de verilmiştir. ${ }^{[21]}$

Tüm bu tanı kriterleri ve biyobelirteçler yine de klinik durum eşliğinde değerlendirilmelidir. Örneğin, immunosüpresif tedavi gören bir hastanın yüksek düzeyde enflamatuvar biyobelirteç üretme olasılı̆̆ının daha düşük, ancak enfeksiyon riskinin daha yüksek olacağı akılda tutulmalıdır. Klinisyenler, bu kriterleri, hastanın sağlığının tüm yönleriyle ilgili mevcut bilgiler bağlamında ve multidisipliner bir ekiple uygulamalıdır. ${ }^{[21]}$

Tablo 1. Parvizi ve ark. tarafından belirtilen PEE için 2018 yılında yayımlanan skorlama sistemi[11]

\begin{tabular}{|c|c|c|c|c|c|}
\hline \multicolumn{3}{|c|}{ Majör kriterler (aşağıdakilerden en az biri) } & \multicolumn{3}{|c|}{ Karar } \\
\hline \multicolumn{3}{|c|}{ Aynı organizmanın iki pozitif kültürü } & \multirow{2}{*}{\multicolumn{3}{|c|}{ Enfekte }} \\
\hline \multicolumn{3}{|c|}{ Eklemle ilişkisi kanıtlanan sinus yolu veya protezin gözüküyor oluşu } & & & \\
\hline \multirow{7}{*}{ 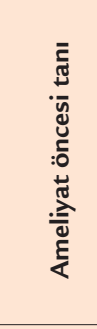 } & \multicolumn{2}{|c|}{ Minör kriterler } & \multirow{2}{*}{$\begin{array}{c}\text { Skor } \\
2\end{array}$} & \multicolumn{2}{|l|}{ Karar } \\
\hline & Serum & Yükselmiş CRP veya $D$-dimer & & \multirow{6}{*}{$\begin{array}{l}\geq 6- \\
2-5- \\
0-1-\end{array}$} & \multirow{6}{*}{$\begin{array}{l}\text { Enfekte } \\
\text { Muhtemel enfekte } \\
\text { Enfekte değil }\end{array}$} \\
\hline & \multirow{5}{*}{ Sinovya } & Yükselmiş ESH & 1 & & \\
\hline & & Yükselmiş sinovyal BK sayısı veya LE & 3 & & \\
\hline & & Pozitif alfa-defensin & 3 & & \\
\hline & & Yükselmiş sinovyal PMNL (\%) & 2 & & \\
\hline & & Yükselmiş sinovyal CRP & 1 & & \\
\hline \multirow{5}{*}{ 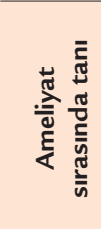 } & Belirsiz a & jncesi skor veya eklem aspirasyonundan materyal elde edilememesi ${ }^{a}$ & Skor & Karar & \\
\hline & Ameliyat & kor & - & \multirow{4}{*}{$\begin{array}{l}\geq 6- \\
4-5- \\
\leq 3-\end{array}$} & \multirow{4}{*}{$\begin{array}{l}\text { Enfekte } \\
\text { Bir sonuca varmayan } \\
\text { Enfekte değil }\end{array}$} \\
\hline & Pozitif h & & 3 & & \\
\hline & Pozitif $p$ & & 3 & & \\
\hline & Tek pozi & & 2 & & \\
\hline
\end{tabular}

"Parvizi J, Tan TL, Goswami K, Higuera C, Della Valle C, Chen AF, Shohat N. The 2018 Definition of Periprosthetic Hip and Knee Infection: An Evidence-Based and Validated Criteria. J Arthroplasty 2018;33(5):1309-14.e2."den alınarak Türkçe'ye çevrilmiştir.

Advers lokal doku reaksiyonları, kristal artropatileri, enflamatuvar artropati alevlenmeleri ve yavaş üreyen mikroorganizmalarla enfeksiyon gibi durumlarda dikkatli olunmalı.

CRP, C-reaktif protein; ESH, eritrosit sedimentasyon hızı; LE, lökosit esteraz; PMNL, polimorfonükleer lökosit; BK, beyaz küre.

${ }^{a}$ Belirsiz minör kriterli hastalar için ameliyat sırasındaki tanı kriterleri, PEE tanısını koymak için kullanılabilir.

'Yeni nesil dizileme (next-generation sequencing - NGS) gibi ileri moleküler tanı araçları kullanmayı düşünün. 
Tablo 2. 2021 yılında yayımlanan Avrupa Kemik ve Eklem Enfeksiyon Cemiyeti (European Bone and Joint Infection Society - EBJIS) tanı kriterleri[21]

$\begin{array}{lll}\begin{array}{l}\text { Enfeksiyon ihtimali düşük } \\ \text { (tüm bulgular negatif) }\end{array} & \begin{array}{l}\text { Enfeksiyon muhtemel } \\ \text { (iki pozitif bulgu) }\end{array} & \begin{array}{l}\text { Enfeksiyon kanıtlanmış } \\ \text { (herhangi bir pozitif bulgu) }\end{array}\end{array}$

Klinik ve kan çalışmaları

\begin{tabular}{|c|c|c|c|}
\hline Klinik özellikler & $\begin{array}{l}\text { İmplant disfonksiyonu için } \\
\text { açık alternatif sebep } \\
\text { (örneğin, kırık, implant yetmezliği, } \\
\text { malpozisyon, tümör) }\end{array}$ & $\begin{array}{l}\text { 1) İmplant uygulanmasından } \\
\text { sonraki ilk beş yıl içinde } \\
\text { gevşemenin radyolojik bulguları } \\
\text { 2) Önceki yara iyileşme } \\
\text { problemleri } \\
\text { 3) Yakın zamanda ateş veya } \\
\text { bakteriyemi hikâyesi } \\
\text { 4) Protez çevresinde pürülans }{ }^{b}\end{array}$ & $\begin{array}{l}\text { Eklemle ilişkisi kanıtlanan } \\
\text { sinus yolu veya protezin } \\
\text { gözüküyor oluşu }\end{array}$ \\
\hline C-reaktif protein & & $>10 \mathrm{mg} / \mathrm{l}(1 \mathrm{mg} / \mathrm{dl})^{c}$ & \\
\hline
\end{tabular}

Sinovyal sıvı sitolojik analizi ${ }^{\text {d }}$

\begin{tabular}{llll}
\hline Lökosit sayısıc $^{c}$ hücre $\left./ \mu l\right)$ & $\leq 1.500$ & $>1.500$ & $>3.000$ \\
PMNL $(\%)^{c}$ & $\leq 65 \%$ & $>65 \%$ & $>80 \%$ \\
\hline
\end{tabular}

\section{Sinovyal sıvı biyobelirteçleri}

Alfa-defensin ${ }^{e}$

Pozitif immunoassay veya

lateral-flow assaye

\section{Mikrobiyolojif}

Aspirasyon sıvisı

\begin{tabular}{llll}
$\begin{array}{l}\text { Ameliyat sırasında } \\
\text { (sıvı ve doku) }\end{array}$ & Tüm kültürler negatif & Tek pozitif kültürg & $\begin{array}{l}\text { Aynı mikroorganizmanın olduğu } \\
\geq 2 \text { pozitif örnek }\end{array}$ \\
$\begin{array}{l}\text { Sonikasyon } \\
\text { (KOB } / \mathrm{ml})\end{array}$ & Üreme yok & $\begin{array}{l}\text { Herhangi bir organizmanın }>1 \\
\text { KOB } / \mathrm{mlg}\end{array}$ & $\begin{array}{l}\text { Herhangi bir organizmanın } \\
\text { KOB } / \mathrm{ml}\end{array}$ \\
\hline
\end{tabular}

$(\mathrm{KOB} / \mathrm{ml})$

Negatif

Tek YBA'da $\geq 5$ nötrofil görülmesi $\quad \geq 5$ YBA'da $\geq 5$ nötrofil görülmesi

Yüksek büyütme alanı

(YBA) (400× büyütme)

Mikroorganizmaların doğrudan görülmesi

\section{Diğerleri}

Nükleer görüntüleme Negatif üç-fazlı izotop kemik taraması ${ }^{c}$ Pozitif BK sintigrafisi

"McNally M, Sousa R, Wouthuyzen-Bakker M, Chen AF, Soriano A, Vogely HC, Clauss M, Higuera CA, Trebše R. The EBJIS definition of periprosthetic joint infection: a practical guide for clinicians. Bone Joint J 2021;103-B(1):18-25."ten alınarak Türkçe'ye çevrilmiştir.

PMNL, polimorfonükleer lökosit; KOB, koloni oluşturan birim; BK, beyaz küre, KK, kırmızı küre, eritrosit.

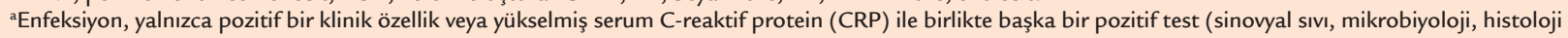
veya nükleer görüntüleme) varsa olasıdır.

${ }^{\mathrm{b}}$ Advers lokal doku reaksiyonu ve kristal artropati olguları hariç.

'Diğer olası enflamasyon nedenleri mevcut olduğunda dikkatle yorumlanmalıdır: gut veya diğer kristal artropati, metalloz, aktif enflamatuvar eklem hastalığı (örneğin, romatoid artrit), periprostetik kırık veya ameliyat sonrası erken dönem.

${ }^{d}$ Bu değerler kalça ve diz periprostetik eklem enfeksiyonu için geçerlidir. Parametreler yalnızca berrak sıvı elde edildiğinde ve lavaj yapılmadı̆̆ında geçerlidir. Analiz hacmi $>250 \mu \mathrm{L}$, ideal olarak $1 \mathrm{ml}$ olmalı, EDTA içeren bir tüpte toplanmalı ve tercihen otomatik teknikler kullanılarak $<1$ saat içinde analiz edilmelidir. Visköz numuneler için hiyalüronidaz ile ön işlem, optik veya otomatik tekniklerin doğruluğunu artırır. Kanlı numuneler olması durumunda, ayarlanmış sinovyal $\mathrm{BK}=$ sinovyal $\mathrm{BK}_{\text {Gö̀lemlenen }}-\left[\mathrm{BK}_{\mathrm{Kan}} / \mathrm{KK}_{\mathrm{Kan}} \times \mathrm{KK}_{\text {sinovyl Swiv }}\right]$ formülü kullanılmalıdır.

eAdvers lokal dokü reaksiyonu, hematom veya akut enflamatuvar artrit veya gut olgularında geçerli değildir.

${ }^{\mathrm{f} A n t i b i y o t i k ~ t e d a v i s i ~ v e r i l m i s ̧ s e ~(b a s i t ~ p r o f i l a k s i ~ d e g ̆ i l), ~ m i k r o b i y o l o j i k ~ a n a l i z ~ s o n u c ̧ l a r ı ~ t e h l i k e y e ~ g i r e b i l i r . ~ B u ~ d u r u m l a r d a ~ m o l e k u ̈ l e r ~ t e k n i k l e r i n ~ y e r i ~ o l a b i l i r . ~ K u ̈ l t u ̈ r ~}$ sonuçları; ameliyat öncesi sinovyal aspirasyondan, ameliyat öncesi sinovyal biyopsilerden veya (tercihen) ameliyat sırasında doku örneklerinden elde edilebilir. sTek pozitif kültürün (veya sonikasyon sıvısında $<50 \mathrm{KOB} / \mathrm{ml}$ ) yorumlanmasında dikkatli olunmalı ve diğer kanıtlarla birlikte ele alınmalıdır. Ameliyat öncesi bir aspirasyon aynı mikroorganizmayı tanımlamışsa, bunlar iki pozitif doğrulayıı örnek olarak kabul edilmelidir. Yaygın olmayan kontaminanlar veya virülan organizmaların (örneğin, Staphylococcus aureus veya Gram negatif basiller), yaygın kontaminanlara (koagülaz negatif stafilokoklar, mikrokoklar veya Cutibacterium acnes gibi) göre enfeksiyonu temsil etme olasılığı daha yüksektir.

hSantrifüj uygulanmışsa, enfeksiyonu doğrulamak için önerilen eşik değeri $200 \mathrm{KOB} / \mathrm{ml}$ 'dir. Protokolde başka varyasyonlar kullanılıyorsa, her protokol için yayımlanan sınır değerler uygulanmalıdır.

iHistolojik analiz, ameliyat öncesi biyopsiden, ameliyat sırasındaki parafinli doku örneklerinden veya donmuş kesit hazırlı̆ından olabilir.

jBK sintigrafisi, önceki taramalara kıyasla (özellikle tamamlayıcı kemik iliği taraması ile kombine edildiğinde) 20 saatlik taramada uptake artarsa, pozitif olarak

kabul edilir. 


\section{TEDAVI SEÇENEKLERi}

Tedavinin hedefleri enfeksiyöz sürecin eradikasyonu ve etkilenen ekstremitenin fonksiyonlarının restore edilmesidir. Tıbbi açıdan mümkün olduğunda protez korunarak veya yeniden bir protez yerleştirilerek fonksiyon restore edilmelidir.

Periprostetik kalça eklemi enfeksiyonunda ideal tedaviye karar verirken; semptomların süresi (akut-kronik), lokal yumuşak doku durumu, kemik stoğu, hastanın daha önce geçirdiği cerrahiler ve bunların sayısı, patojenin tanımlanması, virülansı ve antibiyotik direnci, hastanın genel durumu, komorbiditeleri ve beklentileri gibi birçok faktör göz önünde bulundurulmalıdır. ${ }^{[7,29]}$

Enfekte kalça artroplastisinin yönetiminde beş ana seçenek mevcuttur:

\section{Antibiyotik ile Baskılama}

Uzun dönemli baskılayıcı antibiyotik kullanımı, yalnızca revizyon cerrahisinin kontrendike veya çok yüksek riskli olduğu hasta grubunda bir seçenektir. Çoklu komorbiditesi olanlar, ileri yaşlı hastalar ve kısa yaşam beklentisi olan hastalar, antibiyotik ile baskılama için adaydır. Bu hastaların implantlarının kabul edilebilir miktarda fikse olduğu durumlarda ve oral antibiyotiklere duyarlı, düşük virülanslı bir etken izole edildiğinde bu tedavi düşünülebilir. ${ }^{[30]}$ Enfeksiyonsuz oranlar (yaklaşık \%40) antibiyotik direncine ve uzun dönem toleransa bağlıdır. ${ }^{[29]}$

\section{Debridman, Yıkama ve İmplantın Korunması}

İmplantın korunması, debridman, modüler parçaların değiştirilmesi, yıkama ve antibiyotik tedavisi, ameliyattan hemen sonraki dönemdeki akut enfeksiyon için veya iyi fikse ve fonksiyonel bir protezin geç akut hematojen enfeksiyonu için endikedir. Semptomların başlangıcından 2-3 hafta sonra uygulanırsa, bu strateji başarılı olmayacağı için, erken cerrahi debridman çok önemlidir. ${ }^{[2]}$ Bu tedavi, akut tip I, tip II (hastanın genel durumunun iyi, protezin stabil ve izole edilen patojenin antibiyotiğe duyarlı olması koşulu ile) ve tip III (hastanın bağışıklık yanıtının yeterli olması, tanının 2-3 haftadan önce konulması ve protezin stabil olması koşulu ile) enfeksiyonu olan hastalarda düşünülebilir. [Periprostetik eklem enfeksiyonları dört gruba ayrılabilir. Tip 1: Enfeksiyonun beklenmediği bir durumda, artroplasti revizyonu sırasında alınan rutin kültürlerde üreme olması; Tip 2: Cerrahiden sonraki ilk bir ay içinde enfeksiyonun tanımlanması; Tip 3: Artroplastiden yıllar sonra, bilinen bir kaynaktan, akut hematojen enfeksiyon gelişmesi; Tip 4: Bir ay veya daha uzun süredir enfeksiyon olması]. ${ }^{[6,29,31-33]}$ Revizyon cerrahisine göre daha az morbidite, daha kısa hastanede kalış ve daha düşük maliyet gibi bazı avantajları sayesinde, nispeten basit bir tedavi olarak bilinir. Raporlanan başarı oranları, çeşitli çalışmalarda \%21 ile \%89 arasında değişmektedir. ${ }^{[7]} 1$ ) Stabil bir implantın olması, 2) yüzeye yapışan mikroorganizmalara karşı aktif olan antimikrobiyal maddelere duyarlılığı olan bir patojen saptanması ve 3 ) enfeksiyon semptomlarının süresinin 4-6 haftadan kısa olması koşulları sağlandığı zaman, başarı oranı değişim artroplastisine benzerdir. ${ }^{[7]}$

Debridman; tüm enfekte ve nekrotik dokuların eksizyonunu, mümkünse çimentonun, kablo ile tellerin, plak ile vidaların ve emilemeyen sütürlerin çıkartılmasını içerir. Debride edilen parçalardan en az bir adet kültür gönderilmelidir. Ayrıca modüler parçaların değiştirilmesi de başarı oranlarını artıracaktır. Protezin iyi fikse olmadığı durumlarda, diğer cerrahi yöntemler düşünülmelidir.

Yıkama; mikroorganizma yükünü azaltmak için yapılmakta olup, Lee ve ark.'nın yaptığı bir çalışmada, implant yüzeyindeki olgunlaşmış biyofilm tabakası için, Betadine topikal solüsyonu (\%10 povidone iodine) gazlı beze emdirilerek 5-10 dakika cerrahi sahada tutulmakta ve ardından $3 \mathrm{~L}$ serum fizyolojik ile yıkama uygulanmaktadır. ${ }^{[7]}$

Optimal antibiyotik tedavisi (antibiyotik seçimi ve kullanım süresi), sonucu etkileyen bir başka önemli değişken olmasına karşın, bu konuda hâlâ tartışmalar mevcuttur. Antibiyoterapi, enfeksiyon hastalıkları uzmanı ile birlikte eşgüdüm içinde planlanmalıdır. Kültürlerin henüz bilinmediği durumda ampirik antibiyotik seçimi ile ilgili az sayıda çalışma olmasına rağmen, sefalosporin grubu ve vankomisin öneren çalışmalar mevcuttur. ${ }^{[3,7]}$ Parenteral antibiyotik tedavisinin süresi değişkenlik göstermekle birlikte, çoğu yazar 4-6 haftalık bir tedavi önermiştir. ${ }^{[3]}$ Toplam antibiyoterapinin süresi ise altı hafta ile altı ay arasında değişmekte olup bu süreye, hastanın klinik durumunun ve kan değerlerinin takibine göre, yine enfeksiyon hastalıkları uzmanı ile birlikte karar verilmelidir. ${ }^{[7]}$

\section{Tek Aşamalı Revizyon}

Buchholz ve ark., 1981 yılında, tek aşamalı revizyon veya diğer adıyla direkt değişim artroplastisini tanımlamışlardır. Bu prosedür, enfekte komponentlerin ve çimentonun titiz bir şekilde çıkartılmasını, kapsamlı bir cerrahi debridmanı ve doğrudan çimentolu total kalça artroplastisi ile rekonstrüksiyonu içerir. ${ }^{[34]}$ Bunlar, altı haftalık bir kültür spesifik oral antibiyotik kullanımı ile kombine edilmelidir. ${ }^{[9]}$ Yeni implante edilen protezler, tipik olarak antibiyotik ilave edilmiş çimento ile fikse edilmekle birlikte, literatürde çimentosuz uygulama örnekleri de mevcuttur. Yoo ve ark., çeşitli çimentosuz implantlarla tedavi edilen 12 
hastanın geriye dönük bir incelemesini yayımlamış ve ortalama 3,6 yıllık takip süresinde $\% 83,3$ implant sağkalımı rapor etmişlerdir. ${ }^{[35]}$

Bu yöntem, enfekte total kalça artroplastisinin yönetiminde çeşitli avantajlara sahiptir. Hastalar, tek bir majör cerrahi geçirmeleri sebebiyle, daha düşük bir kümülatif ameliyat dönemi riskine maruz kalmaktadır. Boşluk doldurucu (spacer) kullanılmadığı için, bununla ile ilgili komplikasyonlar görülmez. Finansal açıdan ve kaynak kullanımı açısından da avantajları mevcuttur. Gecikmiş rekonstrüksiyon nedeniyle oluşabilecek olan teknik zorlukları da azaltır.

Jackson ve ve Schmalzried, hangi faktörlerin başarılı sonuçla ilişkili olduğunu belirlemek için bir literatür taraması yapmışlardır. Son takipte genel enfeksiyonsuz oran \%83 olarak bildirilmiştir. Başarıyla ilişkili faktörler; 1) ilk total kalça artroplastisinden sonra yara komplikasyonlarının olmaması, 2) genel sağlık durumunun iyi olması, 3) duyarlı Staphylococcus veya Streptococcus spp. ve 4) çimentodaki antibiyotiğe duyarlı bir mikroorganizmanın izole edilmesi olarak belirtilmiştir. Kötü sonuçlarla ilişkili faktörler ise; 1) polimikrobiyal enfeksiyon, 2) gram-negatif mikroorganizmalar, özellikle Pseudomonas ve 3 ) MRSA (metisilin dirençli Staphylococcus aureus) ve grup D Streptococcus olarak belirtilmiştir. Yazarlar, çimentosuz implantların veya kemik grefti kullanımının enfeksiyon riskini artırabileceğini ve bu nedenle tekniğe kontrendikasyon olabileceğini öne sürmüşlerdir. ${ }^{[36]}$ Ancak daha önce de belirtildiği üzere, tek aşamalı revizyonlarda çimentosuz protez uygulamaları ve ayrıca antibiyotik ilave edilmiş kemik grefti uygulamaları da kullanılabilmektedir. ${ }^{[37]}$

\section{4. İki Aşamalı Revizyon}

íki aşamalı revizyon, genel olarak, enfekte total kalça artroplastisinin tedavisinde altın standart olarak kabul edilmektedir. Literatürde \%90'ın üzerinde eradikasyon oranları bildirilmiştir. [7] iki aşamalı revizyonda, olası tüm enfekte yumuşak dokular ile kemik radikal bir şekilde debride edilir ve çimento dâhil tüm bileşenler çıkartılır. ${ }^{[37]}$

Daha sonra lokal antibiyotikler, antibiyotik yüklü boncuklar veya boşluk doldurucu kullanılarak uygulanır ve ölü alan yönetimi gerçekleştirilir. Boşluk doldurucular, statik veya eklemleşen olarak sınıflandırılır. Statik boşluk doldurucular, implantın çıkarılmasından sonra ölü boşluk içinde bırakılan antibiyotik yüklü bloklardan veya boncuklardan oluşur. Eklemleşen boşluk doldurucular da kendi içinde gruplara ayrılır. Monoblok boşluk doldurucular, metal bir iskelet tarafindan desteklenen bir antibiyotikli çimento protezinden oluşur. Boşluk doldurucular prefabrik veya el yapımı (ameliyat sırasında yapılır) olabilir; bunlar, antibiyotiklerin yüksek konsantrasyonda lokal olarak salınmasına izin verir. Eklemleşen boşluk doldurucular, aşamalar arasında uygun uzuv uzunluğunu ve doku gerginliğini korur ve böylece işlev korunmuş olur. Ancak, antibiyotikli boşluk doldurucuların bu avantajlarına rağmen dezavantajları da mevcuttur. Antibiyotiğe bağlı böbrek fonksiyon bozukluğu, implant migrasyonu, dislokasyon, yapısal başarısızlık ve çıkartılmalarındaki zorluklar bunlardan bazılarıdır. ${ }^{[29]}$ Ayrıca enfeksiyona neden olan mikroorganizmanın bilinmediği durumlarda, boşluk doldurucu uygun antibiyotikleri içermeyebilir. Çimentonun mekanik bütünlüğünü korumak için, antibiyotiklerin çimentoya oranı, kullanılan toplam çimentonun \%10'unu geçmemelidir (yani 40 gr çimentoda toplam $4 \mathrm{gr}$ antibiyotik). En sık eklenen antibiyotikler arasında; tobramisin, gentamisin ve vankomisin bulunur. Meropenem ve linezolid de çimentoya eklenebilecek diğer antibiyotikler arasındadır. ${ }^{[37]}$

İkinci aşama (yeniden implant yerleştirme)'dan önce uygulanacak antibiyotik tedavisinin süresi konusunda bir fikir birliği yoktur. Literatürde, ameliyat sonrası antibiyotik kullanılmamasından, uzun süreli intravenöz antibiyotik kullanımına kadar çeşitli protokoller mevcuttur. Çoğu klinik, devamında oral antibiyotik tedavisi olan veya olmayan, 4-6 haftalık intravenöz antibiyotik tedavisi uygulamaktadır. ${ }^{[37]}$ Sistemik antibiyotikler, kültür sonuçlarına ve organizmaların duyarlılıklarına göre seçilmelidir. Hastalar klinik olarak takip edilmeli ve düzenli olarak CRP ve ESH seviyeleri kayıt altına alınmalıdır. Klinik takiplere göre, gerekli durumlarda, tekrarlayan debridmanlar ve boşluk doldurucu değişimi düşünülmelidir. Lee ve ark.'nın yaptığı bir çalışmada, artmış debridman sıklığı; artan komorbidite $(p<0,001)$, düşük ameliyat öncesi Harris kalça skoru $(p<0,001)$, antibiyotik direnci ve polimikrobiyal kültür sonuçları $(p<0,001)$ ile anlamlı şekilde korele bulunmuştur. ${ }^{[7]}$

Yeniden implant yerleştirme, sıklıkla 6-12 haftada gerçekleştirilir ve bu süre birçok faktöre bağlı olarak değişebilir. ${ }^{[29]}$ Klinik belirtilerin çözülmesi, tekrarlayan aspirasyonların kültür negatif gelmesi, CRP ve ESH kan belirteçlerinin normalleşmesi ile birlikte enfeksiyonun eradike edildiği kabul edilir; bundan sonra ikinci aşamaya geçilir. Bu aşamada CRP ve ESH değerlerinin, enfeksiyon sonlanmasına rağmen normalleşmeyebileceği de göz önünde bulundurulmalı ve yaraların iyileşmesi, hastanın genel iyilik hali, antibiyotiklere cevabı, kemik stoğu gibi klinik bulgular eşliğinde değerlendirilmelidir. İkinci aşama sırasında da, implant yerleştirmeden hemen önce donmuş kesit örnekleri gönderilerek enfeksiyon olmadığı teyit edilebilir. ${ }^{[37]}$ 
íkinci aşama rekonstrüksiyon, çimentolu ve çimentosuz tespit seçeneklerini içerir. Kemik stoğunun yeterli olduğu durumlarda çimentolu implantların kullanılması, antibiyotikli çimento kullanımına izin verir. Çimentosuz tespit için yapılan ilk girişimler olumsuz sonuçlar gösterse de, modern çimentosuz implantların kullanıldığı son raporlar benzer etkinlik göstermiştir. ${ }^{[29]}$ Ciddi kemik defektleri için ise son zamanlarda antibiyotik yüklü impaksiyon greftleme tekniği önerilmiştir. ${ }^{[38]}$

íki aşamalı revizyonun çeşitli avantajları vardır. İki aşamalı revizyon; enfektif yükü ortadan kaldırır ve debridmandan sonra biyofilm altındaki geriye kalan bakteriler açığa çıkar, boşluk doldurucudan yüksek konsantrasyonda antibiyotik salınımı tam eradikasyona yardımcı olur. Ayrıca, daha önce de belirtildiği gibi, eklemleşen boşluk doldurucular, kısmi de olsa eklem hareketliliğini, uygun uzuv uzunluğunu ve aşamalar arasında yumuşak doku gerginliğini korumaya ve fonksiyonel sonucu iyileştirmeye yardımcı olur. İki aşamalı revizyonun bir başka avantajı, kemik ve yumuşak doku defektlerinin daha iyi değerlendirilmesine ve bu doğrultuda rekonstrüksiyon planının yapılabilmesine olanak sağlamasıdır. Ancak iki aşamalı revizyonun bu başarısına ve avantajlarına rağmen, özellikle son yıllarda antibiyotiklere karşı gelişen direnç bu tedavi yönteminde de bir sorun olarak karşımıza çıkmaktadır. ${ }^{[7]}$

\section{Kurtarıcı Cerrahi Yöntemler}

Enfeksiyon kontrolü için tekrarlayan başarısız girişimlerde ve hayatı tehdit eden durumlarda, son çare olarak, rezeksiyon artroplastisi (Girdlestone prosedürü) ve hatta amputasyon, bir seçenek olarak karşımıza çıkmaktadır. Rezeksiyon artroplastisini gerçekleştirme kararı; bakterinin antibiyotik tedavisine direncine, lokal yumuşak dokuların kalitesine, rekonstrüksiyonun karmaşıklığına, hastanın implant çıkartıldıktan sonra başka bir ameliyat olmayı reddetmesine, hastanın genel sağlık durumuna veya bu faktörlerin bir kombinasyonuna dayanır. Rezeksiyon artroplastisi, ağrının kontrol edilmesini sağlayabilmekle birlikte, daha düşük fonksiyonel skorlara sahiptir. Bu hastalar, ameliyattan sonra bacak uzunluk eşitsizliği olacağı, ayakkabı içi yükseltici kullanmaları gerekeceği, yürüyüşlerinde belirgin bir aksama olacağı ve destekle yürümeleri gerekeceği konularında bilgilendirilmelidir. ${ }^{[3,37]}$

\section{SONUÇ}

Kalça PEE, kalça artroplastisi sonrası karşımıza çıkabilen, nadir görülen, ancak iyi yönetilmezse ciddi morbiditelere ve hatta mortaliteye sebep olabilen, zorlayıcı komplikasyonlardan biridir. Tanısı, tedavisi ve yönetimi oldukça zor olabilen ve dikkat gerektiren karmaşık bir durumdur.
Tanıda en önemli durum klinik şüphedir ve şüphenin ardından, iyi bir anamnez alınmalı, klinik belirti ve bulgular ile risk faktörleri ayrıntılıca sorgulanmalı ve fizik muayene ile ortaya konmalıdır. Biyokimyasal testler, görüntüleme yöntemleri, eklem sıvısı analizi, histolojik ve mikrobiyolojik analizler ve bunların kombinasyonları ve tanı kriterleri kullanılarak tanı kesinleştirilmelidir. Günümüzde kalça PEE'nin kesin bir tanı testi veya kriteri bulunmamakla birlikte, her geçen gün yeni tanısal testler keşfedilmekte ve tanı kriterleri güncellenmektedir. Güncel olarak, Parvizi ve ark.'nın 2018 kriterleri ve EBJIS kriterleri kullanılabilir.

Tedavi seçenekleri arasında; "antibiyotik ile baskılama", "debridman, yıkama ve implantın korunması", "tek aşamalı revizyon", "iki aşamalı revizyon" ve "kurtarıcı cerrahi yöntemler (rezeksiyon artroplastisi ve amputasyon)" bulunmaktadır. En uygun tedaviye, hasta özelinde ve hasta ile işbirliği içinde karar verilmeli, güncel bilgiler ışığında tedavi süreci yönetilmelidir.

Kalça artroplastisi ile uğraşan her cerrahın, kalça PEE konusunda uyanık ve bilgili olması, tanı ve tedavideki gelişmeleri yakından takip etmesi ve bu zor ve uzun süreci titiz bir şekilde yönetmesi gerekmektedir.

\section{KAYNAKLAR}

1. Kühn K-D, ed. Management of Periprosthetic Joint Infection. Berlin Heidelberg: Springer; 2018. Crossref

2. Matar HE, Stritch P, Emms N. Infected total hip replacements: assessment and management. Br J Hosp Med 2018;79(5):265-9. Crossref

3. Kaltsas DS. Infection after total hip arthroplasty. Ann R Coll Surg Engl 2004;86(4):267-71. Crossref

4. Breznicky J, Hlavac M, Novak M, Hrncar M. Risk factors for periprosthetic joint infection of the hip and knee. Med Glas 2020;17(1):92-7. Crossref

5. Ting NT, Della Valle CJ. Diagnosis of Periprosthetic Joint Infection -An Algorithm-Based Approach. J Arthroplasty 2017;32(7):2047-50. Crossref

6. Aumiller WD, Kleuser TM. Recognizing and managing infections in total joint arthroplasty. J Am Acad Physician Assist 2015;28(6):37-41. Crossref

7. Lee HD, Prashant K, Shon WY. Management of Periprosthetic Hip Joint Infection. Hip Pelvis 2015;27(2):63. Crossref

8. Parvizi J, Gehrke T, Chen AF. Proceedings of the International Consensus on Periprosthetic Joint Infection. Bone Joint J 2013;95-B(11):1450-2. Crossref

9. George DA, Khan M, Haddad FS. Periprosthetic joint infection in total hip arthroplasty: prevention and management. $\mathrm{Br} J$ Hosp Med 2015;76(1):12-7. Crossref

10. Zmistowski B, Parvizi J. Identification and treatment of infected total hip arthroplasty. Expert Rev Anti Infect Ther 2012;10(4):509-18. Crossref

11. Parvizi J, Tan TL, Goswami K, Higuera C, Della Valle C, Chen AF, Shohat N. The 2018 Definition of Periprosthetic Hip and Knee Infection: An Evidence-Based and Validated Criteria. J Arthroplasty 2018;33(5):1309-14.e2. Crossref 
12. Ouyang Z, Li H, Liu X, Zhai Z, Li X. Prosthesis infection: diagnosis after total joint arthroplasty with three-phase bone scintigraphy. Ann Nucl Med 2014;28(10):994-1003. Crossref

13. Zanetti M. The Expanding Role of MRI in the Evaluation of Periprosthetic Hip Joint Infection. Radiology 2020;296(1):10910. Crossref

14. American Academy of Orthopaedic Surgeons Diagnosis and Prevention of Periprosthetic Joint Infections EvidenceBased Clinical Practice Guideline. https://www.aaos.org/ globalassets/quality-and-practice-resources/pji/pji-clinicalpractice-guideline-final-9-18-19-.pdf

15. Chryssikos T, Parvizi J, Ghanem E, Newberg A, Zhuang H, Alavi A. FDG-PET Imaging Can Diagnose Periprosthetic Infection of the Hip. Clin Orthop Relat Res 2008;466(6):1338-42. Crossref

16. Meermans G, Haddad FS. Is There a Role for Tissue Biopsy in the Diagnosis of Periprosthetic Infection? Clin Orthop Relat Res 2010;468(5):1410-7. Crossref

17. Zmistowski B, Della Valle C, Bauer TW, Malizos KN, Alavi A, Bedair H, Booth RE, Choong P, Deirmengian C, Ehrlich GD, Gambir A, Huang R, Kissin Y, Kobayashi H, Kobayashi N, Krenn V, Lorenzo D, Marston SB, Meermans G, Perez J, Ploegmakers JJ, Rosenberg A, Simpendorfer C, Thomas P, Tohtz S, Villafuerte JA, Wahl P, Wagenaar F-C, Witzo E. Diagnosis of Periprosthetic Joint Infection. J Arthroplasty 2014;29(2 Suppl):77-83. Crossref

18. Shahi A, Parvizi J. The role of biomarkers in the diagnosis of periprosthetic joint infection. EFORT Open Rev 2016;1(7):275-8. Crossref

19. Chen Y, Kang X, Tao J, Zhang Y, Ying C, Lin W. Reliability of synovial fluid alpha-defensin and leukocyte esterase in diagnosing periprosthetic joint infection (PJI): a systematic review and metaanalysis. J Orthop Surg Res 2019;14(1):453. Crossref

20. Deirmengian CA, Liang L, Rosenberger JP, Joaquim TR, Gould MR, Citrano PA, Kardos KW. The Leukocyte Esterase Test Strip Is a Poor Rule-Out Test for Periprosthetic Joint Infection. J Arthroplasty 2018;33(8):2571-4. Crossref

21. McNally M, Sousa R, Wouthuyzen-Bakker M, Chen AF, Soriano A, Vogely HC, Clauss M, Higuera CA, Trebše R. The EBJIS definition of periprosthetic joint infection: a practical guide for clinicians. Bone Joint J 2021;103-B(1):18-25. Crossref

22. Parvizi J, McKenzie JC, Cashman JP. Diagnosis of Periprosthetic Joint Infection Using Synovial C-Reactive Protein. J Arthroplasty 2012;27(8 Suppl):12-6. Crossref

23. Gollwitzer $H$, Dombrowski $Y$, Prodinger PM, Peric M, Summer B, Hapfelmeier A, Saldamli B, Pankow F, von Eisenhart-Rothe R, Imhoff AB, Schauber J, Thomas P, Burgkart R, Banke IJ. Antimicrobial Peptides and Proinflammatory Cytokines in Periprosthetic Joint Infection. J Bone Joint Surg Am 2013;95(7):644-51. Crossref

24. Toms AD, Davidson D, Masri BA, Duncan CP. The management of peri-prosthetic infection in total joint arthroplasty. J Bone Joint Surg Br 2006;88-B(2):149-55. Crossref

25. Atkins BL, Athanasou N, Deeks JJ, Crook DW, Simpson $H$, Peto TE, McLardy-Smith P, Berendt AR. Prospective Evaluation of Criteria for Microbiological Diagnosis of Prosthetic-Joint Infection at Revision Arthroplasty. The OSIRIS Collaborative Study Group. J Clin Microbiol 1998;36(10):2932-9. Crossref
26. Della Valle CJ, Scher DM, Kim YH, Oxley CM, Desai P, Zuckerman JD, Di Cesare PE. The role of intraoperative gram stain in revision total joint arthroplasty. J Arthroplasty 1999;14(4):500-4. Crossref

27. Trampuz A, Piper KE, Jacobson MJ, Hanssen AD, Unni KK, Osmon DR, Mandrekar JN, Cockerill FR, Steckelberg JM, Greenleaf JF, Patel R. Sonication of Removed Hip and Knee Prostheses for Diagnosis of Infection. N Engl J Med 2007;357(7):654-63. Crossref

28. Shohat N, Bauer T, Buttaro M, Budhiparama N, Cashman J, Della Valle CJ, Drago L, Gehrke T, Marcelino Gomes LS, Goswami K, Hailer NP, Han SB, Higuera CA, Inaba Y, Jenny J-Y, Kjaersgaard-Andersen P, Lee M, Llinás A, Malizos K, Mont MA, Jones RM, Parvizi J, Peel T, Rivero-Boschert S, Segreti J, Soriano A, Sousa R, Spangehl M, Tan TL, Tikhilov R, Tuncay I, Winkler $\mathrm{H}$, Witso E, Wouthuyzen-Bakker M, Young S, Zhang X, Zhou Y, Zimmerli W. Hip and Knee Section, What is the Definition of a Periprosthetic Joint Infection (PJI) of the Knee and the Hip? Can the Same Criteria be Used for Both Joints?: Proceedings of International Consensus on Orthopedic Infections. J Arthroplasty 2019;34(2S):S325-7. Crossref

29. Karachalios T, Koutalos A, Komnos G. Management Strategies for Infected Total Hip Arthroplasty. A Critical Appreciation of Problems and Techniques. HIP Int 2014;24(10_suppl):44-7. Crossref

30. Wouthuyzen-Bakker M, Nijman JM, Kampinga GA, van Assen S, Jutte PC. Efficacy of Antibiotic Suppressive Therapy in Patients with a Prosthetic Joint Infection. J Bone Jt Infect 2017;2(2):77-83. Crossref

31. Gomes LSM. Early Diagnosis of Periprosthetic Joint Infection of the Hip -Current Status, Advances, and Perspectives. Rev Bras Ortop (Sao Paulo) 2019;54(4):368-76. Crossref

32. Segawa H, Tsukayama DT, Kyle RF, Becker DA, Gustilo RB. Infection After Total Knee Arthroplasty. A Retrospective Study of the Treatment of Eighty-One Infections. J Bone Joint Surg Am 1999;81(10):1434-45. Crossref

33. Tsukayama DT, Estrada R, Gustilo RB. Infection after Total Hip Arthroplasty. A Study of the Treatment of One Hundred and Six Infections. J Bone Joint Surg Am 1996;78(4):512-23. Crossref

34. Buchholz H, Elson R, Engelbrecht E, Lodenkamper $\mathrm{H}$, Rottger J, Siegel A. Management of deep infection of total hip replacement. J Bone Joint Surg Br 1981;63-B(3):342-53. Crossref

35. Yoo JJ, Kwon YS, Koo K-H, Yoon KS, Kim Y-M, Kim HJ. One-stage cementless revision arthroplasty for infected hip replacements. Int Orthop 2009;33(5):1195-201. Crossref

36. Jackson WO, Schmalzried TP. Limited Role of Direct Exchange Arthroplasty in the Treatment of Infected Total Hip Replacements: Clin Orthop Relat Res 2000;381:101-5. Crossref

37. Senthi S, Munro JT, Pitto RP. Infection in total hip replacement: meta-analysis. Int Orthop 2011;35(2):253-60. Crossref

38. Buttaro MA. Bone Grafting and Two-Stage Revision Total Hip Arthroplasty. HIP Int 2012;22(8_suppl):69-74. Crossref 